\begin{tabular}{|l|l}
\hline JURNAL & JURNAL \\
Pendidikan Dasar dan Keguruan \\
Volume 5, No. 1, 2020 \\
ISSN (print) $:$ :2527-578X \\
ISSN (Print) $: 2715-6818$ \\
Homepage $\quad:$ http://journal.iaimsinjai.ac.id/index.php/JPDK \\
\hline
\end{tabular}

\title{
KETERAMPILAN MEMBACA MELALUI PENGALAMAN BERBAHASA SISWA KELAS AWAL SD MUHMMADIYAH KUPANG
}

\author{
Ahmad $^{1}$ \\ ${ }^{1}$ Universitas Muhammadiyah Kupang \\ ahmadckp08@gmail.com
}

\begin{abstract}
Abstrak
Penelitian ini bertujuan untuk (1) mendeskripsikan peningkatan kemampuan membaca siswa Kelas II SD Muhammadiyah Kupang setelah pengajaran membacanya didesain dengan pendekatan pengalaman berbahasa, (2) mendeskripsikan perubahan perilaku siswa Kelas II SD Muhammadiyah Kupang .Penelitian ini menggunakan desain penelitian tindakan kelas yang bersiklus. Subjek penelitian adalah kemampuan membaca siswa Kelas II SD Muhammadiyah Kupang yang berjumlah 34 siswa. Data penelitian diperoleh dengan menggunakan instrumen tes dan nontes. Hasil penelitian dianalisis secara kualitatif dan kuantitatif. Dari pelaksanaan penelitian siklus I diperoleh hasil bahwa secara individu masih ada beberapa siswa yang mendapatkan nilai di bawah standart $(<70)$ dan secara klasikal berhasil mencapai angka 74,26 atau mencapai kategori nilai baik. Angka ini mengalami peningkatan sebesar 8,24 \% menjadi 80,38 atau mencapai kategori nilai sangat baik pada pelaksanaan penelitian siklus II karena pada penelitian siklus II siswa cenderung aktif tanyajawab, berkomentar kritis, memperhatikan dengan sungguh-sungguh, dan antusias dalam menceritakan kegemarannya. Hal ini menunjukkan bahwa telah terjadi perubahan perilaku siswa ke arah yang lebih baik dan positif antara penelitian siklus I dan siklus
\end{abstract}

Kata Kunci: Membaca, Pendekatan Pengalaman Berbahasa

\begin{abstract}
This study aims to (1) describe the increase in reading ability of Class II students of Muhammadiyah Kupang Elementary School after the teaching of reading is designed with a language experience approach, (2) describe the change in behavior of Class II students of Muhammadiyah Kupang Elementary School. This study uses a cyclical classroom action research design. The subject of the study was the reading ability of Class II students of Muhammadiyah Kupang Elementary School with a total of 34 students. Research data were obtained using test and non-test instruments. The results of the study were analyzed qualitatively and quantitatively. From the implementation of the first cycle of research, it was found that individually there were still a few students who scored below the standard $(<70)$ and classically managed to reach 74.26 or reach the good grades category. This figure has increased by $8.24 \%$ to 80.38 or achieved very good category in the implementation of the second cycle research because in the second cycle research students tend to be active question-answer, critical comment, pay attention seriously, and enthusiastic in telling their hobbies. This shows that there has been a change in student behavior for the better and more positive between the research cycle I and cycle
\end{abstract}

Keyword: Reading, Approach to Language Experience 


\section{Pendahuluan}

Keterampilan membaca sangat memegang peranan penting dalam kehidupan manusia, karena pengetahuan apapun tidak dapat dipisahkan dari kegiatan membaca. Hal ini dikarenakan bahwa semua cabang ilmu pengetahuan yang ada, disajikan dalam bentuk bahasa tulis yang dikemas dalam bentuk sebuah buku Oleh sebab itulah, penguasaan keterampilan membaca sangat diperlukan setiap orang agar ia dapat mentransfer semua ilmu pengetahuan dari buku ke dalam pikirannya. Jadi tanpa keterampilan membaca semua pengetahuan akan terasa sia-sia dan tak bermanfaat. Sejalan dengan hal itu, Tarigan (Yunus Abidin 2012:59) Membaca pemahaman (reading for undersanding) adalah jenis membaca untuk memahami standar-standar atau norma kesastraan, resensi kritis, drama tulis, dan pola-pola fiksi dalam usaha memperoleh pemahaman terhadap teks, pembaca menggunakan strategi tertentu.

Pembelajaran membaca di SD dilaksanakan sesuai dengan pembedaan atas kelaskelas awal dan kelas-kelas tinggi. Pelajaran membaca dan menulis di kelas-kelas awal disebut pelajaran membaca dan menulis permulaan, sedangkan di kelas-kelas tinggi disebut pelajaran membaca dan menulis lanjut. Pelaksanaan membaca permulaan di kelas I sekolah dasar dilakukan dalam dua tahap, yaitu membaca periode tanpa buku dan membaca dengan menggunakan buku. Pembelajaran membaca tanpa buku dilakukan dengan cara mengajar dengan menggunakan media atau alat peraga selain buku misalnya kartu gambar, kartu huruf, kartu kata dan kartu kalimat, sedangkan membaca dengan buku merupakan kegiatan membaca dengan menggunakan buku sebagai bahan Pelajaran. (Sri Nuryati, 2007:1-2)

Siswa Kelas II SD Muhammadiyah Kupang, adalah salah satu sekolah dasar negeri di Kota Kupang yang mengalami masalah dengan pengajaran membaca. Dari hasil wawancara dengan guru wali kelas, yang sekaligus sebagai guru pengajar materi membaca di kelas 1 dan 2, diperoleh kesimpulan bahwa prestasi membaca mereka sangatlah rendah. Rendahnya kualitas membaca mereka teridentifikasi dari kecepatan membaca, rendahnya minat baca, dan kualitas membaca mereka yang masih terbata-bata, serta rendahnya pemahaman terhadap isi bacaan. Salah satu upaya yang telah dilakukan guru untuk mengatasi masalah di atas adalah dengan menyuruh siswa agar selalu berlatih membaca dan meningkatkan intensitas membacanya. Dengan demikian, diharapkan kualitas membaca siswa dapat berangsur membaik dan akhirnya diperoleh prestasi membaca siswa yang lebih baik dari sebelumnya.

Upaya yang guru lakukan sebenarnya tidak keliru, karena secara teori, orang yang sering membaca kualitas membacanya akan berangsur menjadi lebih baik. Namun tidak demikian halnya dengan masalah yang dihadapi oleh siswa dan guru di SD ini. Setelah dimotivasi, bukannya siswa menuruti anjuran guru untuk terus berlatih membaca, tetapi justru mereka semakin enggan untuk melakukan aktivitas membaca. Ketika disuruh membaca, meskipun dengan bersusah payah dan terbata-bata, mereka sanggup menyelesaikannya. Akan tetapi, ketika ditanya apa isi bacaan yang baru saja dibaca, mereka hanya diam dan kelihatan bingung. Masalah ini sebenarnya bukan masalah intern yang hanya dialami oleh siswa dan guru Kelas II SD Muhammadiyah Kupang, melainkan selalu terjadi setiap tahun ajaran baru pada jenjang pendidikan yang sama tanpa mengenal batas lokasi sekolah. Informasi ini diperoleh dari keterangan guru pengajar kelas Kelas II SD Muhammadiyah Kupang. 


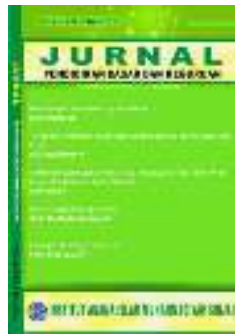

JURNAL

Pendidikan Dasar dan Keguruan

Volume 5, No. 1, 2020

ISSN (print) : 2527-578X

ISSN (Print) : :2715-6818

Homepage : http://journal.iaimsinjai.ac.id/index.php/JPDK

Pendekatan pengalaman berbahasa adalah salah satu pendekatan pengajaran membaca yang memang diformulasikan untuk meningkatkan minat baca dan prestasi membaca siswa sekolah dasar kelas rendah (kelas 1 dan kelas 2). Pendekatan yang didasarkan atas pengalaman anak dalam menggunakan bahasanya ini, melalui prosesnya dalam kegiatan belajar mengajar, diharapkan dapat menemukan dan mengembangkan bahan pelajaran membaca yang cocok untuk siswa kelas 1 dan 2 sekolah dasar. Karena dalam proses belajar mengajar membaca yang dikembangkan melalui pendekatan pengalaman berbahasa ini, dapat dihasilkan sebuah bahan ajar membaca yang secara serempak bisa mengembangkan keterampilan menyimak, berbicara, membaca, dan menulis sekaligus (Muchlisoh 1996:223-224). Selain itu, bahan ajar membaca yang dihasilkan dalam proses belajar mengajar melalui pendekatan pengalaman berbahasa akan menghasilkan sebuah wacana yang sesuai dengan pengalaman, minat, lingkungan, kebutuhan, dan kemampuan siswa kelas 2 sekolah dasar. Dengan adanya beberapa keunggulan-keunggulan tentang pengajaran membaca yang didesain dengan pendekatan pengalaman berbahasa seperti yang telah diuraikan di atas, maka penelitian ini akan mengujicobakan pendekatan pengalaman berbahasa untuk mengatasi permasalahan tentang prestasi membaca yang sedang dialami oleh siswa dan guru kelas Kelas II SD Muhammadiyah Kupang, dengan menggunakan desain penelitian tindakan kelas (action research).

Membaca merupakan salah satu keterampilan berbahasa di samping tiga aktivitas berbahasa yang lainnya. Di antara keempat keterampilan tersebut dapat dibagi menjadi dua kelompok besar yaitu keterampilan yang bersifat menerima/reseptif (pasif), yang meliputi keterampilan menyimak dan membaca. serta keterampilan yang bersifat mengungkapkan/produktif (aktif) yang meliputi Faktorfaktor yang mempengaruhi proses membaca pemahaman Lamb dan Arnol (Samsu Somadaya 2011:27).

\section{a. Faktor Lingkungan}

Faktor lingkungan yaitu mencakup latar belakang dan pengalaman siswa serta sosial ekonomi. latar belakang dan pengalaman siswa saling berkaitan dalam kemajuan membaca siswa. Lingkungan siswa dapat membentuk pribadi, sikap, nilai, dan kemampuan bahasa anak. Kondisi di rumah memengaruhi pribadi dan penyesuain diri anak dalam masyarakat. Kedua hal tersebut dapat membantu dan dapat menghalangi anak belajar membaca. Anak yang tinggal di rumah tangga yang harmonis, rumah yang penuh dengan cinta kasih, yang orang tuanya memahami anak-anaknya, tidak akan menemukan kendala yang berarti dalam membaca. Sebaliknya jika anak yang tinggal di rumah tangga yang tidak harmonis akan menemukan kendala yang berarti dalam membaca. Faktor sosial ekonomi, orang tua, dan lingkungan merupakan faktor yang membentuk lingkungan rumah siswa. Beberapa peneliti mengungkapkan bahwa semakintinggi status sosial ekonomi siswa semakin tinggi kemampuan verbal siswa.

\section{b. Faktor Intelektual}

Faktor intelektual yaitu mencakup metode pengajar guru dan prosedur kemampuan guru. Intelektual atau inteligensi merupakan suatu kegiatan berpikir yang terdiri dari pemahaman yang esensial tentang situasi yang diberikan dan meresponnya secara tepat. Faktor intelektual berperan penting dalam memengaruhi kemampuan membaca siswa. Guru yang menggunakan metode yang bervariasi dan tepat tidak akan membuat siswa jenuh dan akan meningkat kemampuan membaca siswa, dan jika guru yang hanya menggunakan metode konvensional akan membuat jenuh siswa sehingga membuat minat membaca siswa rendah sehingga siswa sulit untuk memahami isi sebuah bacaan.

\section{c. Faktor Psikologis}




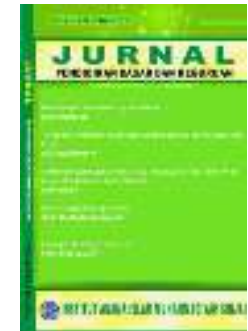

JURNAL

Pendidikan Dasar dan Keguruan

Volume 5, No. 1, 2020

ISSN (print) : 2527-578X

ISSN (Print) : :2715-6818

Homepage : http://journal.iaimsinjai.ac.id/index.php/JPDK

Faktor psikologis yaitu mencakup motivasi, minat, kematangan sosial, emosi, dan penyesuaian diri. Motivasi merupakan factor kunci dalam belajar membaca. Kuncinya adalah guru harus mendemonstrasikan kepada siswa praktik pengajaran yang relevan dengan minat dan pengalaman anak sehingga anak memahami belajar itu sebagai kebutuhan. Siswa yang mempunyai motivasi tinggi terhadap membaca, akan mempunyai minat yang tinggi pula terhadap kegiatan membaca. Selain motivasi dan minat, kematangan sosial, emosi, dan percaya diri sangat penting dalam kemajuan belajar membaca. Anak-anak yang mudah marah, menangis, bereaksi secara berlebihan ketika mereka tidak mendapatkan sesuatu akan mendapat kesulitan dalam pelajaran membaca, sebaliknya anak-anak yang lebih mudah mengontrol emosinya akan lebih mudah memusatkan perhatiannya pada teks yang dibacanya. Percaya diri sangat dibutuhkan oleh anak-anak. Anak-anak yang kurang percaya diri di dalam kelas, tidak akan bisa mengerjakan tugas yang diberikan oleh guru walaupun tugas itu sesuai dengan kemampuan yang dimiliki.

\section{d. Faktor Fisiologi}

Faktor fisiologis yaitu mencakup kesehatan fisik dan pertimbangan neurologis. Gangguan pada alat bicara, alat pendengaran, dan alat penglihatan bisa memperlambat kemajuan belajar membaca. Analisis bunyi misalnya, mungkin sukar bagi anak yang mempunyai masalah pada alat bicara dan alat pendengaran. Kelelahan juga merupakan kondisi yang tidak menguntungkan bagi anak untuk belajar, khususnya belajar membaca. Beberapa ahli mengemukakan bahwa keterbatasan neurologis (berbagai cacat otak) merupakan salah satu faktor yang dapat menyebabkan anak gagal dalam meningkatkan kemampuan membaca pemahaman.

Salah satu kesulitan yang dihadapi guru bahasa Indonesia dalam pengajaran membaca adalah menemukan bahan pelajaran yang cocok bagi para anak didiknya.. Untuk mengatasi hal tersebut para guru mencoba suatu pendekatan berdasarkan latar belakang pengalaman anak dalam menggunakan bahasanya. Pendekatan ini disebut Pendekatan Pengalaman Berbahasa (PPB). Dalam PBB, guru menggunakan bahan pelajaran yang dibuat oleh siswa itu secara tertulis. Dengan demikian anak akan berkesimpulan bahwa segala sesuatu yang dilisankannya itu dapat diubah menjadi tulisan. Kesadaran seperti itu penting sekali. Dengan kesadaran tersebut anak-anak pun akan berkesimpulan bahwa tulisan itu bisa bercerita, bahwa dengan tulisan orang biasaberkomunikasi, bahwa dengan tulisan itu mempunyai persamaan dengan tutur.

PPB dalam bidang membaca dapat dibatasi sebagai pengajaran membaca dengan menggunakan wacana yang dikembangkan bersama-sama dengan anak-anak. Dalam PBB guru merangsang anakanak untuk berpikir tentang pengalaman masing-masing. Guru memberikan dorongan kepada anakanak untuk bercerita. Waktu anak bercerita, guru mendengarkan cerita itu dan merekamnya secermat-cermatnya. Rekaman guru yang menggunakan huruf-huruf yang jelas itu harus dilakukan di depan anak-anak supaya anak-anak sadar bahwa bahasa lisan itu bisa diubah menjadi bahasa tulisan. Wacana yang berbentuk deretan kata, frase, kalimat, atau cerita itulah yang dijadikan bahan pelajaran. Belajar konstrultivisme mengisyaratkan bahwa guru tidak memompakan pengetahuan ke dalam kepala pebelajar, melainkan pengetahuan diperoleh melalui suatu dialog yang ditandai oleh suasana belajar yang bercirikan pengalaman dua sisi. Ini berarti bahwa penekanan bukan pada kuantitas materi, melainkan pada upaya agar siswa mampu menggunakan otaknya secara efektif dan efisien sehingga tidak ditandai oleh segi kognitif belaka, melainkan oleh keterlibatan emosi dan kemampuan kreatif. Dengan demikian proses belajar membaca perlu disesuaikan dengan kebutuhan perkembangan siswa (Semiawan, 2002:5).

Dalam PPB guru mengembangkan wacana bersama-sama dengan murid-muridnya mulai dengan memberikan rangsangan pada pikiran murid-muridnya itu. Langkah yang pertama, ialah pengembangan wacana bersama salah satu murid, guru menyuruhnya memikirkan hal-hal yang 


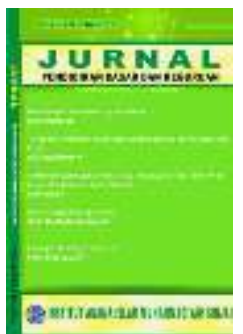

JURNAL

Pendidikan Dasar dan Keguruan

Volume 5, No. 1, 2020

ISSN (print) : 2527-578X

ISSN (Print) : :2715-6818

Homepage : http://journal.iaimsinjai.ac.id/index.php/JPDK

merupakan kesukaannya. Guru memotivasi dengan jalan berkata bahwa dia ingin tahu kesenangannya. Dalam hal yang kedua, guru mulai dengan jalan bercerita bahwa hari Minggu merupakan hari libur untuk beristirahat. Dia melukiskan hal-hal yang suka dikerjakannya pada hari Minggu, kemudian dia merangsang muridnya untuk bepikir tentang apa yang suka mereka kerjakan pada hari Minggu.Langkah yang kedua, guru berupaya untuk mendengarkan sebaik-baiknya dan mengarahkan percakapan yang langsung antara murid-muridnya. Sepintas lalu, upaya yang harus dilakukan guru itu mudah; namun, dalam suatu kelompok yang terdiri atas banyak murid, pekerjaan mengarahkan pembicaraan mereka supaya setiap anak mendapat giliran untuk mengemukakan pendapatnya itu, bukanlah hal yang sederhana. Guru menyuruh murid-murid yang berkelompok itu mendengarkan baik-baik temannya yang sedang berbicara. Masalah yang dihadapi dalam hal ini sudah tentu berbeda dengan yang dihadapi pada waktu menggunakan PPB dengan seorang anak. Langkah yang ketiga ialah menuliskan hal-hal yang ceritakan oleh murid. Bisaanya guru memberikan petunjuk kepada muridnya supaya yang dikemukakannya itu berupa sebuah cerita. Guru memberi contoh cara memulai sebuah cerita, atau yang lebih baik ialah meminta saran murid tentang cara yang mereka sukai. Semua saran haris diperhatikan dan murid disuruh memilih cara yang terbaik. Kalimat-kalimat yang mendukung kalimat yang pertama yang merupakan awal cerita itu, akan diajukan oleh murid. Guru mencatat kalimat-kalimat yang mereka buat itu tepat sebagaimana yang diucapkan murid. Langkah yang keempat, guru mendengarkan bacaan muridnya. Guru menyuruh muridnya. Guru menyuruh meuridnya membaca wacana yang merupakan hasil rekamannya itu. Jika dia bekerja dengan seorang siswa, maka dia harus memperhatikan kata-kata yang dikenal muridnya dan kata-kata mana yang tidak dikenalnya. Jika guru bekerja dengan sekelompok murid, dia bisa menyuruh murid-muridnya membaca secara bergiliran. Guru mencatat kata-kata yang diucapkan oleh murid-muridnya itu tidak ada dalam wacana Langkah yang kelima merupakan penggunaan wacana dalam pengajaran membaca. Guru harus memanfaatkan pengetahuan yang diperolehnya dari bacaan murid-muridnya itu. Kalau guru tahu bahwa siswanya tidak dapat membaca kata tertentu yang ada dalam wacana yang digunakannya itu, dia harus mengajarkannya dengan cara memisahkan kata tertentu itu dari wacana .

Salah satu manfaat PPB yang sangat penting adalah sifat PPB yang mulai dengan soal perkembangan bahasa anak. Tugas untuk memilih bahan yang cocok menjadi ringan karena wacana yang digunakan sudah dengan sendirinya sesuai dengan tingkat penguasaan bahasa anak. Selain itu kelebihan yang lain ialah sifatnya yang mengintegrasikan semua kegiatan kebahasaan. Anak-anak mendengarkan, berbicara, membaca, dan kadang-kadang menuliskan wacana yang tengah dikembangkan. Kelebihan lain dari PPB adalah sifatnya yang bisa meningkatkan minat baca siswa, karena PPB berpusat pada anak. Orang pada umumnya senang membaca pengalaman pribadinya. Anak-anak pun sama, terutama terhadap wacana yang memerikan komentar yang positif tentang dirinya. Tugas untuk memotivasi anak memmbaca wacana tidak diperlukan pada PPB. Kelebihan yang terakhir yang dimiliki PPB ialah kehematannya. PPB tidak memerlukan biaya banyak. PPB cukup dengan kertas, papan tulis, pensil, dan kapur yang ada. Pendekatan lain kerap kali tidak bisa berjalan karena tuntutan pembiayaan yang terlalu tinggi.

Disamping memiliki kelebihan, PPB mempunyai beberapa kelemahan, yang pertama ialah sifat PPB yang hanya digunakan pada pelajaran membaca tingkat awal. Setelah anak menguasai kosakata dasar, dia akan memerlukan bahan bacaan yang berisi pengalaman dan kosakata baru. Kalau guru hanya menggunakan PPB, anak-anak akan terbatas ruang geraknya di sekitar pola bahasa dan pengalamannya saja. Salah satu tujuan utama membaca ialah untuk memperkaya kosakata dan berbagai tipe pola bahasa haruslah digunakan dalam upaya meluaskan pengembangan bahasa. PPB juga menuntut waktu yang jauh lebih banyak bila dibandingkan dengan pendekatan-pendekatan lain karena sesungguhnya guru selalu berupaya mengembangkan bahan yang diperlukan oleh PPB tidak melihat hal-hal di atas itu sebagai keterbatasan, tetapi sebagai kesempatan yang bekerja lebih banyak lagi dengan anak secara perorangan. PPB menuntut guru agar selalu menyadari adanya sejumlah 


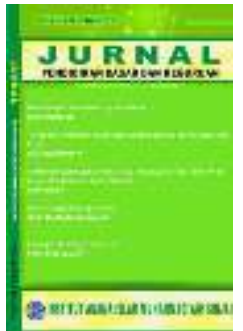

JURNAL

Pendidikan Dasar dan Keguruan

Volume 5, No. 1, 2020

ISSN (print) : 2527-578X

ISSN (Print) : :2715-6818

Homepage : http://journal.iaimsinjai.ac.id/index.php/JPDK

keterampilan membaca dan sejumlah kata-kata sehngga mereka tahu apa yang harus diajarkan dan kapan mengajarkannya. Pedoman guru yang menyertai pendekatan lainnya memberikan kemudahan bagi guru. Di dalamnya dijelaskan kata-kata yang mana yang harus diperkenalkan kepada murid dan keterampilan apa yang harus diajarkan. PPB tidak menyajikan hal-hal yang memudahkan seperti itu.

\section{Metode}

Penelitian mengenai keterampilan membaca melalui pendekatan pengalaman berbahasa ini merupakan penelitian tindakan kelas. Penelitian tindakan kelas merupakan suatu pencermatan terhadap kegiatan yang sengaja dimunculkan dan terjadi dalam sebuah kelas (Arikunto 2006:19). Desain penelitian yang digunakan adalah desain penelitian model tindakan kelas (PTK) (action research). Penelitian dilakukan dengan dua siklus, masing-masing siklus dilaksanakan melalui empat tahap. Keempat tahap ini adalah tahap perencanaan (planning), tindakan (acting), pengamatan (observing), dan refleksi (reflecting). adalah tahap perencanaan (planning), tindakan (acting), pengamatan (observing), dan refleksi (reflecting). Berikut adalah bagan untuk menggambarkan rangkaian siklus dan masing-masing tahapnya.

Subjek dalam penelitian ini adalah kemampuan membaca pada siswa Kelas II SD Muhammadiyah Kupang sebanyak 34 siswa. Kemampuan membaca yang dimaksud adalah kemampuan membaca siswa dalam hal (1) ketepatan pengucapan kosakata bahasa Indonesia, (2) penguasaan tanda baca (pungtuasi) sederhana, (3) kelancaran membaca, (4) keajegan volume suara, (5) kestabilan kecepatan membaca, (6) tingkat pemahaman bacaan, (7) dan perilaku siswa pada saat proses pembelajaran membaca berlangsung.

Dalam penelitian ini, ada dua variabel penelitian, yang pertama adalah kemampuan membaca siswa, dan yang kedua adalah pendekatan pengalaman berbahasa. Kedua variabel ini kemudian dipadupadankan menjadi sebuah judul dan permasalahan yang diangkat menjadi sebuah penelitian. Tentang kedua variabel. Bentuk instrumen penelitian ini dapat berupa tes dan nontes. Instrumen tes berupa tes lisan dan tes tertulis, sedangkan instrumen nontes berupa pedoman diagnosis perilaku siswa, pedoman wawancara, serta dokumentasi foto. Berkaitan dengan bentuk instrumen dan cara kerja dari masing-masing instrumen, berikut adalah penjelasannya.

Penelitian siklus I dilaksanakan melalui empat tahap. Tahap ini meliputi tahap perencanaan, tahap tindakan, tahap pengamatan, dan tahap refleksi. Keempat tahap ini harus dilaksanakan secara berurutan dan sistematis sesuai dengan apa yang sudah direncanakan. Siklus I dilaksanakan selama dua hari dengan dua kali pertemuan/tatap muka, masing-masing tatap muka dibutuhkan dua jam pelajaran (total 120 menit : 2 x pertemuan : @ = 30 menit). Pelaksanaan siklus I dilakukan pada 20 Mei 2019 dan Jumat, 21 Mei 2019 (selanjutnya disebut hari pertama dan hari kedua penelitian). Hari pertama dilakukan untuk membentuk wacana dan pengamatan perilaku siswa pada saat mengikuti pembelajaran membaca yang didesain dengan pendekatan pengalaman berbahasa, kemudian hari kedua dilakukan untuk melakukan evaluasi kemampuan membaca siswa dengan menggunakan wacana hasil pembelajaran yang didesain dengan pendekatan pengalaman berbahasa, pengukuran tingkat keterpahaman siswa terhadap isi bacaan dengan tes objektif pilihan ganda, penilaian perilaku siswa, serta wawancara dengan siswa yang dilakukan setelah pembelajaran usai. Penelitian siklus II dilakukan sebagai tindak lanjut dari refleksi yang dilakukan pada siklus I. Cara kerja siklus II sesuai dengan tahap-tahap yang dilakukan pada siklus I, tetapi ada sedikit perbedaan terhadap cara kerja 


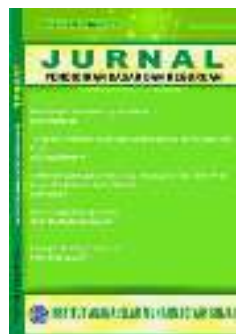

JURNAL

Pendidikan Dasar dan Keguruan

Volume 5, No. 1, 2020

ISSN (print) : 2527-578X

ISSN (Print) : 2715-6818

Homepage : http://journal.iaimsinjai.ac.id/index.php/JPDK

pengambilan data di kelas. Perbedaan cara kerja ini disebabkan karena adanya perbaikkan terhadap kekuranganไrevisi pada pelaksanaan siklus I. Dengan demikian, dari pelaksanaan penelitian siklus II diharapkan akan diperoleh hasil kemampuan membaca siswa yang lebih baik daripada hasil penelitian siklus I dan yang paling penting, hasilnya akan sesuai dengan sasaran/target.

Tahap refleksi pada siklus II dilakukan untuk mencari tahu apakah peningkatan kemampuan membaca siswa telah dicapai dan sesuai dengan sasaran, serta untuk mencari tahu sejauh mana perubahan perilaku siswa ketika pembelajaran membacanya didesain dengan PPB. Apabila dari tahap refleksi siklus II diperoleh hasil yang menunjukkan adanya peningkatan kemampuan membaca siswa, serta diperoleh perubahan perilaku siswa yang positif dan sesuai dengan apa yang sudah ditargetkan, maka peningkatan maupun perubahan perilaku ini merupakan jawaban atas kedua permasalahan yang dikemukakan pada Bab I butir 1.4. Hal ini juga merupakan petunjuk bahwa pendekatan pengalaman berbahasa mampu meningkatkan kemampuan membaca siswa Kelas II SD Muhammadiyah Kupang, sesuai dengan teori hipotesis tindakan yang telah diajukan pada Bab II butir 2.2.10.

Penelitian siklus II dilaksanakan pada Senin, 20 juni 2019 dan Selasa, 21 juni 2019. Desain penelitian masih tetap menggunakan desain penelitian model tindakan kelas yang dilaksanakan melalui empat tahap. Tahap ini adalah perencanaan, tindakan, pengamatan, dan refleksi. Masingmasing tahap dilaksanakan sama dengan penelitian pada siklus I. Hanya saja, pada siklus II ada sedikit perbaikkan pada tahap perencanaan dan skenario pembelajaran pada tahap tindakan. Tujuan perbaikkan ini adalah agar dalam penelitian siklus II nanti diperoleh hasil yang sesuai dengan sasaran dan diperoleh perubahan perilaku siswa yang positif.

\section{Hasil dan Pembahasan Hasil dan Pembahasan}

\section{Hasil}

Hasil penelitian ini terdiri atas hasil penelitian prasiklus, hasil penelitian siklus I, dan hasil penelitian siklus II. Kegiatan prasiklus difungsikan untuk mengetahui kondisi awal kemampuan membaca siswa sebelum pembelajaran membacanya didesain dengan pendekatan pengalaman berbahasa. Hasil penelitian siklus I dan siklus II adalah hasil tes kemampuan membaca siswa setelah pembelajarannya didesain dengan pendekatan pengalaman berbahasa.

Pada tahap ini, peneliti melakukan pengukuran kemampuan membaca siswa dengan menggunakan wacana hasil kutipan sebuah buku teks (Aku Cinta Bahasa Indonesia IB oleh Surana) dan pembelajarannya tidak didesain dengan pendekatan pengalaman berbahasa. Buku ini adalah buku yang disepakati oleh guru dan pihak sekolah sebagai buku pegangan mata pelajaran bahasa dan sastra Indonesia. Dari pengukuran prasiklus, diketahui ada beberapa siswa yang berperilaku tak relevan ketika mengikuti pembelajaran di kelas. Perilaku ini seperti melamun/mengantuk, bicara tak relevan, mencari perhatian orang lain, tak mau membaca, kurang antusias mengikuti pembelajaran, dan tak memperhatikan. Dari prasiklus diketahui pula bahwa hasil tes kemampuan membaca siswa Kelas II SD Muhammadiyah Kupang tergolong rendah. Hal ini dapat dilihat berikut ini.

Berdasarkan hasil penilaian kemampuan membaca siswa Kelas II SD Muhammadiyah Kupang. Menunjukkan bahwa kemampuan membaca siswa kelas 1 secara klasikal mencapai angka rata-rata 74,26. Hal ini berarti bahwa secara klasikal kemampuan membaca siswa mencapai kategori baik. Walaupun secara klasikal kemampuan membaca siswa sudah memenuhi target atau sasaran 


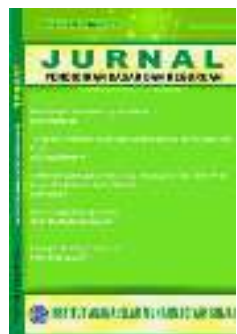

JURNAL

Pendidikan Dasar dan Keguruan

Volume 5, No. 1, 2020

ISSN (print) : 2527-578X

ISSN (Print) : :2715-6818

Homepage : http://journal.iaimsinjai.ac.id/index.php/JPDK

(target $\geq 70$ ) dan sudah masuk dalam kategori nilai baik, tetapi secara individu masih ada siswa yang memperoleh nilai di bawah standar. Maksud dari nilai di bawah standar adalah nilai kurang dari 70,00 (<70). Secara rinci nilai tes kemampuan membaca siklus I ada 8 siswa atau sebesar 23,53\% yang mencapai kategori nilai kurang, 2 orang siswa atau sebesar 5,88 \% mencapai kategori nilai cukup, 11 siswa atau sebesar 32,35 \% mencapai kategori nilai baik, dan 13 siswa atau sebesar 38,24 $\%$ berhasil mencapai kategori nilai sangat baik.

Hasil perolehan nilai di atas apabila dibandingkan dengan nilai prasiklus (dalam kapasitas alat penilaian yang sama) terjadi peningkatan sebesar 6,17 atau mengalami peningkatan sebesar 9,06 \%. Nilai prasiklus secara klasikal mencapai angka 68,09, setelah pembelajaran membacanya didesain dengan pendekatan pengalaman berbahasa meningkat menjadi 74,26. Hasil penelitian nontes terdiri dari hasil diagnosis perilaku siswa pada saat mengikuti pembelajaran membaca yang didesain dengan pendekatan pengalaman berbahasa. Hasil wawancara merupakan jawaban dari 15 responden, hasil catatan guru yang berkaitan dengan pelaksanaan pembelajaran membaca yang tertuang dalam, serta hasil "jepretan" foto berikut deskripsinya. Hasil secara rinci dari instrumen nontes ini dapat dilihat pada uraian berikut ini.

Pengamatan perilaku siswa dilakukan oleh peneliti yang dibantu oleh rekan peneliti. Pengamatan ini dilakukan terhadap seluruh siswa dari awal hingga akhir proses pembelajaran. Tidak hanya perilaku negatif saja yang diamati, tetapi perilaku positif yang mendukung proses pembelajaran juga harus diamati guru. Perilaku yang ditunjukkan siswa pada waktu mengikuti pembelajaran dituangkan atau dicatat guru ke dalam sebuah pedoman diagnosis perilaku siswa yang telah dipersiapkan sebelumnya. Secara rinci hasil dari pengamatan/diagnosis perilaku siswa dapat dilihat pada uraian berikut ini. Berdasarkan pengamatan terhadap perilaku siswa pada waktu mengikuti pembelajaran membaca di kelas, sebagian besar siswa menunjukkan perilaku relevan (positif) yang mendukung proses pembelajaran. Mendukung dalam artian membantu kelancaran pelaksanaan pembelajaran membaca yang didesain dengan pendekatan pengalaman berbahasa serta mendukung dalam artian membantu diri siswa untuk dapat memahami penjelasan, perintah, dan petunjuk guru, sehingga mereka mendapatkan nilai yang lebih baik dari sebelumnya. Perilaku ini ditunjukkan oleh sebagian siswa yang aktif melakukan tanya-jawab dengan guru pada saat proses pembelajaran, ada yang berkomentar kritis dalam menyikapi penjelasan guru, ada yang menghindari hal-hal yang mengganggu proses belajaranya, dan ada yang sangat antusias dalam menceritakan kegemarannya. Keadaan ini menyebabkan pembelajaran membaca yang didesain dengan pendekatan pengalaman berbahasa mampu menciptakan wacana yang sesuai dengan karakter siswa. Sementara itu, sikap mau membaca secara individu maupun bersama-sama dan sikap yang mau memperhatikan dengan sunguh-sungguh penjelasan guru dari awal sampai akhir pembelajaran merupakan wujud perilaku positif siswa.

Hasil wawancara diperoleh kesimpulan bahwa mereka yang mendapat nilai tinggi dan sedang mengaku tidak ada kesulitan menceritakan kegemarannya. Mereka justru senang ketika harus menceritakan kegemarannya. Sementara itu, mereka yang mendapat nilai rendah mengaku tidak tahu apakah mereka senang atau tidak, ada kesulitan atau tidak ketika harus menceritakan kegemarannya. Hal ini dikarenakan mereka merasa tidak dilibatkan dalam tanya-jawab seputar makanan kegemaran mereka (tidak ditanya guru apakah makanan kesukaannya) dan tidak dilibatkan dalam proses pembentukan wacana. Jadi mereka kesulitan mendeskripsikan perasannya tentang apakah mereka senang atau kesulitan ketika menceritakan tentang makanan kesukaannya. Hasil penelitian siklus II berupa hasil penilaian tes dan nontes. Hasil penilaian tes adalah hasil penilaian terhadap tes tertulis dan tes lisan. Hasil penilaian nontes berupa hasil dari pengamatan perilaku siswa, hasil wawancara, dan hasil dokumentasi foto. Seluruh hasil penilaian ini adalah hasil perhitungan dari pelaksanaan penelitian siklus II yang telah dilaksanakan pada 20 juni 2019 sampai dengan 21 Juni 2019 Perlu diketahui bahwa pelaksanaan siklus II merupakan tindak lanjut dari penelitian siklus I dengan 


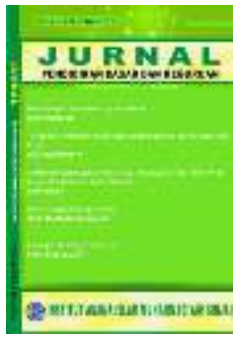

JURNAL

Pendidikan Dasar dan Keguruan

Volume 5, No. 1, 2020

ISSN (print) : 2527-578X

ISSN (Print) : :2715-6818

Homepage : http://journal.iaimsinjai.ac.id/index.php/JPDK

beberapa revisi pada masing-masing tahap siklusnya. Tes lisan berupa hasil penilaian terhadap kemampuan membaca teknik siswa, sedangkan tes tertulis merupakan hasil penilaian terhadap tes objektif pilihan ganda sebagai sarana untuk mengukur tingkat keterpahaman siswa

Hasil penilaian kemampuan membaca pada siklus II terlihat bahwa secara klasikal berhasil mencapai angka 80,38 atau berhasil mencapai kategori nilai sangat baik. Dua atau 5,88\% siswa mencapai kategori nilai cukup, 14 atau $41,18 \%$ berhasil mencapai kategori nilai baik, dan 18 siswa atau 52,94\% mencapai kategori sangat baik. Diketahui dari hasil penelitian siklus II telah terjadi peningkatan nilai sebesar 6,12 atau Meningkat sebesar 8,24\% apabila dibandingkan dengan hasil penelitian siklus I. Pada siklus I berhasil mencapai angka rata-rata 74,26 atau berhasil mencapai kategori nilai baik dan pada siklus II berhasil mencapai angka rata-rata 80,38 atau mencapai kategori nilai sangat baik. Hasil penilaian nontes dari penelitian tindakan kelas siklus II adalah hasil dari kerja pedoman diagnosis perilaku siswa pada saat mengikuti pembelajaran membaca di dalam kelas, hasil dari proses wawancara yang terkumpul dari 15 orang responden yang mewakili kategori nilai yang berbeda, Hasil dokumentasi peristiwa pada saat pengambilan data yang berbentuk foto berikut dengan deskripsinya. Hasil dari kerja instrumen nontes secara keseluruhan dan lebih rinci pada saat pengambilan data siklus II dapat dilihat pada uraian berikut ini.

Masih seperti pada penelitian siklus I hasil dari diagnosis perilaku siswa akan dituangkan ke dalam sebuah lembaran diagnosis perilaku siswa. Dari pelaksanaan pengambilan data siklus II, terutama pada pelaksanaan pembelajaran membaca di kelas, terjadi beberapa perubahan perilaku siswa dari perilaku negatif yang cenderung merugikan, ke arah perilaku positif yang cenderung menguntungkan bagi pelaksanaan pembelajaran dan bagi anak didik. Beberapa perilaku yang tidak relevan untuk dilakukan di dalam kelas seperti melamun, mengantuk, berbicara yang tidak relevan, mencari perhatian orang lain, mengganggu teman, tidak atau kurang antusias dalam menceritakan kegemarannya, dan sikap yang tidak mau memperhatikan dengan sungguh-sungguh, yang sebelumnya dilakukan siswa pada saat pembelajaran membaca siklus I, tidak lagi terjadi pada pembelajaran siklus II. Siswa cenderung aktif tanya jawab, berkomentar kritis, memperhatikan dengan sungguh-sungguh, dan lebih banyak siswa yang lebih antusias dalam menceritakan kegemarannya. Perilaku siswa yang demikian akan membawa dampak yang lebih baik terhadap hasil belajar siswa dan secara lebih khusus akan berakibat pada meningkatnya prestasi membaca siswa. Meskipun demikian, masih ada satu orang siswa yang melakukan beberapa tindakan yang kurang relevan pada saat proses pembelajaran. Perilaku ini dilakukan oleh responden dengan nomer urut 21. Siswa ini masih menunjukkan perilaku yang tak terpuji, seperti berbicara yang tidak relevan dan mengganggu teman sebangkunya. Walaupun demikian, perilaku siswa ini tidak mendapatkan tanggapan dari teman sebangku sehingga lama-kelamaan perilaku ini hilang dengan sendirinya. Meskipun masih ada satu orang yang masih melakukan tindakan yang tidak relevan, namun secara keseluruhan proses pembelajaran membaca di dalam kelas pada penelitian siklus II cenderung berjalan dengan sangat kondusif, lancar, dan sesuai dengan apa yang diharapkan.

Terjadinya perubahan perilaku ini akibat dari penerapan disiplin yang dilakukan oleh guru (peneliti) saat proses pembelajaran di dalam kelas. Bentuk penerapan kedisiplinan ini adalah seperti sikap sedikit lebih keras guru tarhadap siswa yang berperilaku negatif, seperti mengganggu teman, tidak memperhatikan dengan sungguh-sungguh, berbicara yang tidak relevan, dan mencari perhatian. Bagi mereka yang melakukan tindakan seperti di atas akan dikenai sangsi berupa ancaman pengurangan nilai dan akan dipulangkan paling akhir. Disamping itu, selama pembelajaran berlangsung siswa tidak boleh ijin keluar kelas mengingat pada pelaksanaan siklus I ada beberapa siswa yang ijin ke luar kelas dengan alasan membuang sampah dan menyerut pensil. Selain itu, bagi mereka yang sengaja ataupun tidak sengaja menjatuhkan benda di dalam kelas, benda itu akan menjadi milik guru. Dengan sikap guru yang demikian, diharapkan siswa akan menjadi lebih 


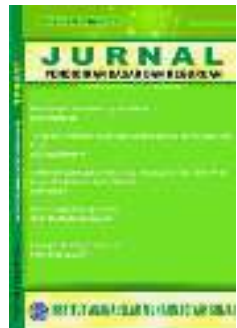

JURNAL

Pendidikan Dasar dan Keguruan

Volume 5, No. 1, 2020

ISSN (print) : 2527-578X

ISSN (Print) : :2715-6818

Homepage : http://journal.iaimsinjai.ac.id/index.php/JPDK

terfokus mengikuti pelajaran di dalam kelas dan lebih berkonsentrasi terhadap materi pembelajaran membaca yang didesain dengan pendekatan pengalaman berbahasa.

Hasil wawancara juga diketahui bahwa mereka tidak ada yang mengalami kesulitan atau hambatan selama pelaksanaan proses pembelajaran dan mereka juga mengaku senang untuk menceritakan pengalaman pribadinya terutama yang berkaitan dengan kegemarannya mengisi liburan semester. Selain itu, mereka dari kategori nilai yang berbeda mengaku senang membaca wacana yang dihasilkan dari proses pembelajaran membaca yang didesain dengan pendekatan pengalaman berbahasa terutama terhadap isi wacana. Wacana berisi tentang kegemaran atau kegiatan siswa dalam mengisi liburan semester dan isi lebih mudah diingat dan dipahami, inilah alasan mengapa siswa senang membaca wacana hasil dari pembelajaran membaca yang didesain dengan pendekatan pengalaman berbahasa.

\section{PEMBAHSAN}

Pada subbab ini akan diuraikan perbandingan hasil penelitian siklus I dan siklus II serta akan diuraikan perubahan perilaku siswa dari siklus I dan siklus II. Perbandingan hasil penelitian merupakan perbandingan hasil nilai tes maupun nontes. Perbandingan hasil tes pada pelaksanaan penelitian siklus I dan siklus II.Berdasarkan hasil perhitungan terhadap hasil perolehan nilai tes penelitian tindakan kelas dalam upaya meningkatan kemampuan membaca siswa Kelas II SD Muhammadiyah Kupang, yang dilakukan pada proses pembelajaran membaca yang didesain dengan pendekatan pengalaman berbahasa. Diketahui telah terjadi peningkatan nilai klasikal sebesar 12,29. Nilai klasikal pada penelitian prasiklus mencapai angka 68,09, meningkat menjadi 74,26 pada siklus I, dan meningkat lagi menjadi 80,38 pada siklus II. Antara hasil prasiklus dengan siklus I mengalami peningkatan sebesar $9,06 \%$, antara hasil penelitian siklus I dengan siklus II mengalami peningkatan nilai sebesar 6,12 atau mengalami peningkatan sebesar 8,24 \%, dan antara hasil prasiklus dengan siklus II mengalami peningkatan sebanyak 12,29 atau sebesar $18,05 \%$.

Pada tahap prasiklus sebanyak 9 siswa mencapai kategori nilai kurang, kemudian berkurang menjadi 8 siswa pada siklus I, dan pada siklus II tak satupun siswa yang masuk dalam kategori nilai ini. Siswa yang mencapai kategori nilai cukup pada penelitian prasiklus sebanyak 6 orang, mengalami penurunan menjadi 2 orang pada siklus I, dan tidak mengalami perubahan pada siklus II. Siswa yang mencapai kategori nilai baik pada penelitian prasiklus mencapai 14 orang, mengalami penurunan menjadi 11 orang pada siklus I, dan meningkat kembali menjadi 14 orang pada siklus II. Jumlah siswa yang mencapai kategori sangat baik pada penelitian prasiklus mencapai 5 orang, meningkat menjadi 13 siswa pada siklus I, dan meningkat lagi menjadi 18 siswa pada penelitian siklus II.

Pada penelitian siklus I, walaupun secara klasikal telah berhasil mencapai target atau sasaran yaitu perolehan nilai mencapai angka lebih dari atau sama dengan $70(\geq 70)$, tetapi secara individu masih ada sejumlah siswa yang mendapakan nilai di bawah standart atau kurang dari angka 70 (< 70). Diketahui masih ada sekitar 10 anak yang mendapat nilai kurang dari 70, bahkan 8 diantaranya mencapai kategori nilai kurang. Oleh karena itulah, penelitian siklus I ini masih jauh dari keberhasilan dan masih perlu diadakan upaya peningkatannya dengan ditetapkannya penelitian siklus II.Tidak demikian halnya dengan hasil nilai siswa pada pelaksanaan tes kemampuan membaca siklus II. Dari hasil perhitungan nilai penelitian siklus II diketahui bahwa secara klasikal maupun individu telah berhasil mencapai angka lebih dari atau sama dengan $70(\geq 70)$. Pelaksanaan penelitian siklus II secara klasikal berhasil mencapai angka 80,38 atau berhasil mencapai kategori nilai sangat baik, dan secara individu semua siswa berhasil mendapat nilai di atas atau sama dengan 70 ( $\geq 70$ ). Di tabel juga terlihat tidak ada siswa yang mencapai kategori nilai kurang dan sebagian besar siswa berhasil mencapai kategori nilai baik. Oleh karena itulah, penelitian siklus II dapat 


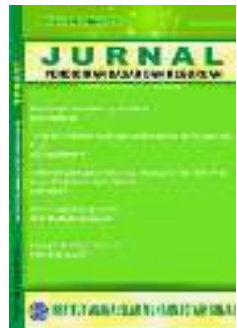

JURNAL

Pendidikan Dasar dan Keguruan

Volume 5, No. 1, 2020

ISSN (print) : 2527-578X

ISSN (Print) : :2715-6818

Homepage : http://journal.iaimsinjai.ac.id/index.php/JPDK

dikatakan berhasil karena antara perolehan nilai klasikal dan nilai individu siswa, masing-masing mencapai angka lebih dari atau sama dengan $70(\geq 70)$. Dengan dasar inilah penelitian tindakan kelas bidang membaca ini tidak perlu berlanjut pada siklus berikutnya dan dapat dikatakan berhasil meningkatkan kemampuan membaca siswa melalui pembelajaran membaca yang didesain dengan pendekatan pengalaman berbahasa.

Peningkatan ini terjadi lantaran upaya guru/peneliti mengevaluasi dan memperbaiki dengan cara mengadakan perubahan pada masing-masing tahap penelitian yang dianggap lemah dan dianggap sebagai penyebab pelaksanan penelitian siklus I kurang berhasil dan tidak mencapai sasaran. Evaluasi pelaksanaan penelitian siklus I dilakukan melalui proses refleksi setelah penelitian siklus I selesai. Hal yang menyebabkan penelitian ini menjadi berhasil dikarenakan adanya faktor guru, siswa, dan kondisi kelas yang saling mendukung dan memungkinkan pelaksanaan pembelajaran membaca yang didesain dengan pendekatan pengalaman berbahasa berjalan dengan lancar, kondusif, dan sesuai dengan harapan. Faktor siswa adalah sikap siswa yang pada penelitian siklus I banyak yang melakukan tindakan kurang terpuji dan cenderung merugikan terhadap proses dan hasil pembelajaran siswa, tetapi pada saat pembelajaran membaca siklus II, perilaku yang kurang relevan ini tidak diulangi dan tidak lagi dijumpai. Perubahan perilaku siswa ini lebih disebabkan karena peran guru yang mampu mengkondisikan kelas, sikap sedikit lebih keras, serta penerapan disiplin pada saat proses pembelajaran membaca di dalam kelas (faktor guru). Selain itu, tindakan guru yang lebih melibatkan siswa yang mendapatkan nilai kurang pada saat penelitian siklus I ke dalam proses pembelajaran, proses tanya-jawab, dan proses pembentukan wacana pada saat pembelajaran siklus II, juga menjadi salah satu faktor penentu keberhasilan siswa.

Keberhasilan penelitian siklus II juga dipengaruhi oleh lingkungan kelas, keadaan sekitar kelas yang sangat gaduh pada saat pelaksanaan siklus I menyebabkan ada beberapa siswa yang mendapatkan nilai kurang, Hal ini diketahui lantaran beberapa dari mereka mengaku terganggu dengan kondisi di luar kelas yang sangat gaduh. Kegaduhan ini lebih disebabkan karena banyak siswa kelas 6 yang berada di luar kelas. Mereka tidak masuk kelas dan tidak ada jam pelajaran setelah mengikuti latihan ujian nasional. Peristiwa seperti ini tidak lagi terjadi pada saat pembelajaran siklus II. Oleh sebab itulah, kondisi lingkungan kelas dan siswa pada saat pembelajaran siklus II dirasa sangat mendukung dan kondusif. Peningkatan nilai klasikal sebesar $8,24 \%$ atau 18,05\% (apabila dibandingkan dengan hasil nilai prasiklus) pada penelitian siklus II, terjadi seiring dengan adanya peningkatan nilai dari masing-masing aspek penilaian membaca teknik. Mulai dari aspek ketepatan pengucapan kosakata bahasa Indonesia, aspek penguasaan terhadap tanda baca sederhana (produktif), aspek kelancaran membaca, aspek volume suara, aspek kecepatan membaca, dan aspek tingkat pemahaman terhadap isi bacaan yang kesemuanya mengalami peningkatan.

Dibawah ini akan diuraikan tentang pembahasan hasil penelitian yang berupa nontes. Pembahasan yang dimaksud adalah hasil proses pembandingan perilaku siswa, jurnal guru, hasil wawancara, dan dokumentasi foto pada penelitian prasiklus, siklus I, dan siklus II. Berdasarkan perbandingan hasil diagnosis perilaku siswa pada pelaksanaan pembelajaran membaca yang didesain dengan pendekatan pengalaman berbahasa antara prasiklus, siklus I, dan siklus II, membuktikan bahwa pada pelaksanaan pembelajaran penelitian siklus II telah terjadi perubahan perilaku ke arah yang lebih baik. Pada proses pembelajaran prasiklus dijumpai banyak sekali siswa yang berperilaku tidak relevan yang cenderung merugikan jalannya pembelajaran. Perilaku-perilaku ini seperti melamiu atau mengantuk, berbicara yang tidak relevan, sikap tak mau membaca, mencari perhatian orang lain, mengganggu teman, kurang antusias mengikuti pembelajaran di kelas serta sikap tidak mau memperhatikan dengan sungguh-sungguh penjelasan guru. Perilaku-perilaku yang negatif di atas mengalami penurunan jumlah pelaku pada pelaksanaan siklus I. Pada siklus I masih dijumpai beberapa siswa yang menunjukkan perilaku yang tidak relevan yang cenderung merugikan bagi 


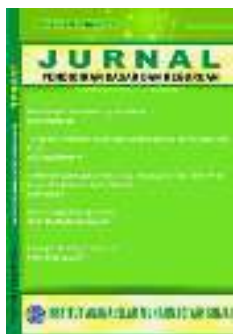

JURNAL

Pendidikan Dasar dan Keguruan

Volume 5, No. 1, 2020

ISSN (print) : 2527-578X

ISSN (Print) : :2715-6818

Homepage : http://journal.iaimsinjai.ac.id/index.php/JPDK

pelaksanaan pembelajaran dan hasil belajar siswa. Perilaku ini seperti sikap melamun, mengantuk, berbicara yang tidak relevan, mencari perhatian orang lain, tidak memperhatikan dengan sungguhsungguh, dan mengganggu teman. Meski demikian, perilaku-perilaku negatif ini sudah mengalami penurunan jumlah pelaku pada saat pembelajaran siklus I.

Sikap-sikap negatif seperti di atas tidak lagi dijumpai pada pelaksanaan pembelajaran penelitian siklus II. Pada siklus II siswa cenderung berperilaku positif yang mendukung keberhasilan pembelajaran dan tujuan pembelajaran. Sikap positif siswa ditunjukkan oleh perilaku siswa yang cenderung aktif tanya- jawab, berkomentar /kritis, menghindari terhadap hal-hal yang mengganggu proses belajarnya, memperhatikan dengan sungguh-sungguh, dan antusias dalam menceritakan kegemarannya. Hal ini menunjukkan bahwa perilaku negatif yang dilakukan sebagian dari siswa pada pelaksanaan siklus I, telah mengalami kemajuan menjadi perilaku positif pada pelaksanaan pembelajaran membaca siklus II. Secara lebih rinci perubahan perilaku siswa yang terjadi menurut aspek observasi dalam pedoman diagnosis perilaku siswa antara siklus I dan siklus II. Dari hasil wawancara juga diketahui bahwa siswa yang mendapatkan nilai rendah pada tes siklus I merasa tidak dilibatkan dalam proses pembelajaran dan pembentukan wacana, dan inilah yang menjadi penyebab sebagian dari mereka tidak dapat menjawab pertanyaan wawancara yang berisi tentang bagaimana perasaan siswa saat menceritakan kegemarannya dan pertanyaan yang berisi tentang hambatan dalam menceritakan kegemarannya. Hal yang demikian tidak lagi terjadi pada saat pelaksanaan penelitian siklus II. Siswa yang semula tidak bisa menjawab beberapa pertanyaan pada siklus I menjadi bisa menjawab pertanyaan serupa pada siklus II. Selain itu, dari hasil wawancara pada siklus I dan siklus II diketahui siswa mengaku senang bila harus membaca bacaan itu, terutama terhadap isinya.

\section{UCAPAN TERIMA KASIH}

Saya sampaikan rasa terima kasih kepada Kepala Sekola SD Muhammadiyah Kupang, yang telah mengizinkan melakukan penelitian di SD Muhammadiyah Kupang, dan kepada guru mata pelajaran yang telah memberikan jam mata pelajaran untuk waktu penelitian.

\section{PENUTUP}

Berdasarkan rumusan masalah dan hasil penelitian tindakan kelas siklus I dan siklus II, serta dari hasil pembahasan, dapat disimpulkan sebagai berikut.

(1) Pembelajaran membaca yang didesain dengan pendekatan pengalaman berbahasa dapat meningkatkan kemampuan membaca siswa Kelas II SD Muhammadiyah Kupang. Hal ini dapat dibuktikan pada hasil nilai tes kemampuan membaca siswa pada masing-masing siklus. Pada siklus I hasil perhitungan nilai tes kemampuan membaca mencapai angka rata-rata 74,26 atau mencapai kategori nilai baik, sedangkan pada siklus II mengalami kenaikkan nilai rata-rata menjadi 80,38 atau mencapai kategori nilai sangat baik. Jika kenaikkan nilai rata-rata ini dipersentasekan, maka persentase kenaikkan nilai mereka mencapai 8,24 \%. Persentase kenaikkan akan menjadi lebih besar apabila hasil nilai rata-rata siklus II dibandingkan dengan nilai rata-rata prasiklus, yaitu mencapai kenaikkan $18,05 \%$.

(2) Perubahan perilaku yang terjadi dari siklus I dan siklus II merupakan perubahan perilaku yang bersifat positif. Perilaku-perilaku yang tidak relevan yang dilakukan siswa pada pelaksanaan pembelajaran siklus I mengalami penurunan jumlah pelaku pada siklus II, sedangkan perilakuperilaku yang relevan yang dilakukan siswa saat proses pembelajaran membaca yang didesain dengan pendekatan pengalaman berbahasa pada penelitian siklus I mengalami peningkatan jumlah pelaku pada pelaksanaan siklus II. Perilaku-perilaku negatif seperti melamun, mengantuk, berbicara yang tidak relevan, mencari perhatian dari orang lain, mengganggu teman, 


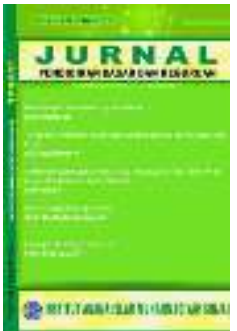

JURNAL

Pendidikan Dasar dan Keguruan

Volume 5, No. 1, 2020

ISSN (print) : 2527-578X

ISSN (Print) : 2715-6818

Homepage : http://journal.iaimsinjai.ac.id/index.php/JPDK

kurang antusias dalam menceritakan kegemarannya, dan siswa tidak memperhatikan dengan sungguh-sungguh, yang dilakukan sebagian siswa pada saat pembelajaran siklus I, mengalami penurunan jumlah pelaku pada siklus II. Tindakan siswa ini lebih dialihkan menjadi perbuatan yang positif seperti siswa menjadi aktif tanya-jawab, kritis, memperhatikan dengan sungguhsungguh, dan menjadi lebih antusias ketika menceritakan kegemarannya. Selain itu, dari hasil wawancara, jurnal guru, dan refleksi, perubahan perilaku lebih ditunjukkan dengan sikap siswa yang mengaku senang dengan pembelajaran membaca yang didesain dengan pendekatan pengalaman berbahasa, senang ketika harus menceritakan kegemarannya, senang dengan isi bacaan, dan senang ketika harus membacanya. Dari hasil kerja instrumen ini juga diketahui bahwa siswa lebih percaya diri melakukan uji kemampuan membaca di depan kelas serta lebih mudah memahami isi wacana yang dihasilkan melalui pembelajaran membaca yang didesain dengan pendekatan pengalaman berbahasa.

\section{DAFTAR PUSTAKA}

Arikunto, Suharsimi. 2006. Prosedur Penelitian Suatu Pendekatan Praktik. Jakarta: Rineka Cipta.

Muchlisoh. 1996. Materi Pokok Bahasa Indonesia 3. Jakarta: Depdikbu

Samsu Somadaya. 2011. Strategi dan Teknik Pembelajaran Membaca. Yogyakarta: Graha Ilmu.

Semiawan, Conny, dkk. 2002. Pendekatan Keterampilan Proses. Jakarta: Gramedia

Sri Nuryati. 2007. Pembelajaran Membaca Permulaan Melalui Permainan Bahasa Di Kelas Awal Sekolah Dasar. Jurnal Sekolah Dasar, (Online), (http://www. Google.com, diakses 20 Maret 2019

Yunus Abidin. 2012. Pembelajaran Membaca Berbasis Pendidikan Karakter. Bandung: Refika. 